\title{
Effect of feeding pattern on the energy metabolism of rats given low-protein diets
}

\author{
BY K. J. MCCRACKEN \\ Agricultural and Food Chemistry Research Division, \\ Department of Agriculture and Queen's University, \\ Newforge Lane, Belfast BT9 ${ }_{5} P X$ \\ (Received 29 July 1974 - Accepted I 5 August 1974)
}

x. The deposition of fat and protein and the utilization of energy by growing rats offered diets ad lib. or in controlled amounts by gastric intubation has been investigated. Diets contained 50,75 , 100 or $200 \mathrm{~g}$ protein $/ \mathrm{kg}$, mainly as casein.

2. Gain of body-weight and protein increased with increasing dietary protein concentration when animals received the same energy intake, although the reverse was true for fat deposition. However, the differences in live-weight gain were almost entirely due to changes in body water. The dry-matter content of the gain in animals given low-protein diets was $770 \mathrm{~g} / \mathrm{kg}$ compared to $360 \mathrm{~g} / \mathrm{kg}$ in those given the control diet.

3. Energy retention was unaffected by dietary protein level in groups given the same energy intake by gastric intubation. In Expt $\mathrm{I}$ daily heat production increased significantly $(P<0.05)$ with increasing protein level $(50,75$ and $200 \mathrm{~g}$ protein $/ \mathrm{kg}$ diet) when energy intake was constant, but in Expt 2 there was no significant effect of protein level $(50,100$ and $200 \mathrm{~g}$ protein/ $\mathrm{kg}$ diet). Problems arose in the selection of a suitable basis for comparison of heat production between groups because of the differences in body-weight and body composition.

4. The energy requirement for zero energy balance was approximately 10\% lower for the low-protein groups than for those given the diet containing $200 \mathrm{~g}$ protein $/ \mathrm{kg}$ when food intake was just above the maintenance level. When the requirement was expressed per unit metabolic body size $\left(W^{0.75} \mathrm{~kg}\right)$ dietary protein level had no significant effect. The mean values for Expts I and 2 were 452 and $436 \mathrm{~kJ}$ respectively.

5. The energy cost of weight gain increased as dietary protein level decreased in pairs of groups gaining at the same rate. The extra energy ingested by the animals given the lower protein level was converted to body tissue with an efficiency of at least 0.70 .

6. Striking differences were observed in body composition and energy retention of the two pairs of groups used for the comparison of tube-feeding and $a d$ lib. feeding. With the diet containing $5 \circ \mathrm{g}$ protein $/ \mathrm{kg}$, tube-fed rats gained significantly more weight $(P<0.0 \mathrm{I})$ and more fat, dry matter and energy $(P<0.00 \mathrm{I})$ than their ad lib. counterparts given an isoenergetic intake.

7. The results demonstrate that dietary protein level has little or no effect on the utilization of energy by growing rats when the pattern of intake is controlled by gastric intubation.

It has been shown that rats given a low-protein diet grow more slowly and retain less energy than litter-mates given a normal diet in isoenergetic amounts (Hogan \& Pilcher, I933; Forbes, Swift, Black \& Kahlenberg, I935; Hamilton, 1939 $a, b$ ). These results have generally been accepted as support for the concept, proposed by Möllgaard (1923) and reiterated by many nutritionists (Mitchell \& Carman, 1926; Fraps, 1931; Hamilton, I939a; Mitchell, 1964), that the utilization of food energy is impaired by improper balance of the essential dietary factors.

However, during a study of this phenomenon using a 'pair-feeding' technique similar to that employed by the early workers, McCracken $(1968 a, b)$ found that the pattern of feeding of animals given a complete diet, at the level of intake reached by those on a low-protein diet, altered drastically. Within a few days they adopted a 
'meal-eating' pattern, consuming the whole of their daily ration in less than $2 \mathrm{~h}$ and in some instances as little as $x_{5}$ min. In contrast, animals given low-protein diets were adequately supplied with food at all times and maintained a normal 'nibbling' pattern. This observation has subsequently been corroborated (Loveless, Williams \& Heaton, 1972; Pocknee \& Heaton, 1974).

It is known that 'meal-eating' as opposed to 'nibbling' results in a greater accumulation of fat and retention of energy when rats are given normal diets in isoenergetic amounts (Cohn, Joseph \& Shrago, 1957; Tepperman \& Tepperman, 1958, 1964; Fabry \& Braun, 1967). It therefore seemed that the results obtained by Hogan \& Pilcher (1933) and by later workers could be attributed to an increased efficiency of energy utilization on normal diets due to a change in feeding pattern, rather than to a decreased efficiency associated with the protein-deficient diets, as had been previously assumed.

To test this hypothesis rats were given low- or normal-protein diets, in isoenergetic amounts, by gastric intubation, to eliminate differences in feeding pattern, or were offered the same diets $a d$ lib.

\section{EXPERIMENTAL}

Two experiments were done. In Expt $\mathrm{r}$ animals were tube-fed three times daily for either 7 or 14 d. In Expt 2 most of the animals were tube-fed but to compare the effect of 'meal-eating' as opposed to 'nibbling' two groups had continuous access to food. The experimental period was $7 \mathrm{~d}$.

\section{Animals}

The rats used were of the Hooded Lister strain, from a highly inbred colony. The young were suckled in litters of eight, weaned at $2 \mathrm{I} d$, and only males were retained for experiments. These were transferred to a room maintained at $28 \pm \mathrm{r}^{\circ}$ and during the pre-experimental period they were kept in groups and offered a diet containing I90 $\mathrm{g}$ protein/kg (Table I, diet I). During the experiment tube-fed animals were caged in groups of two or three and the ad lib.-fed animals were caged individually.

\section{Diets and measurement of food intake}

The composition of the diets is outlined in Table I. Diets I, 3 and 4 were used in Expt I and diets I, 2 and 4 in Expt 2. For tube-feeding the diets were mixed to a slurry with water immediately before each feed. The dry-matter (DM) content of all diets was approximately $0.7 \mathrm{~g} / \mathrm{ml}$ of slurry. At each feed random samples were taken for DM determinations, using the same method of dispensing the samples as in the actual tube-feeding operation.

The rats fed ad lib. were offered the food in powder form. Circular food-pots of $50 \mathrm{~mm}$ diameter and $25 \mathrm{~mm}$ depth were used. The food was packed firmly into the pot. When the rats were fed in this way from weaning, food spillage was minimal. Sufficient food was offered to ensure that they had continuous access and the foodpots were weighed and replenished each morning. 
Table I. Composition and analysis of diets $(\mathrm{g} / \mathrm{kg})$ given to rats

Dextrin
Sucrose
Casein
DL-Methionine
Dried yeast
Maize oil
Vitamin mixture*
Mineral mixture†
Dry matter
Fat
Protein
Gross energy $(\mathrm{MJ} / \mathrm{kg})$
$\quad(\mathrm{Mcal} / \mathrm{kg})$

\begin{tabular}{|c|c|c|c|}
\hline \multicolumn{4}{|c|}{ Diet } \\
\hline I & 2 & 3 & 4 \\
\hline $\begin{array}{l}300^{\circ} 0 \\
284^{\circ} \circ\end{array}$ & $\begin{array}{l}440 \cdot 0 \\
268 \cdot 0\end{array}$ & $\begin{array}{l}475^{\circ} \circ \\
268 \cdot 5\end{array}$ & $\begin{array}{l}500 \cdot 0 \\
268 \cdot 5\end{array}$ \\
\hline $230^{\circ} 0$ & 170.0 & $75^{\circ} \circ$ & 50.0 \\
\hline 6.0 & $2 \cdot 0$ & $\mathrm{I} \cdot 5$ & $\mathrm{I} \cdot 5$ \\
\hline 20.0 & $20 \cdot 0$ & 20.0 & 20.0 \\
\hline 100.0 & 100.0 & 100.0 & 100.0 \\
\hline $20 \cdot 0$ & 20.0 & $20 \cdot 0$ & 20.0 \\
\hline 40.0 & 40.0 & $40 \cdot 0$ & 40.0 \\
\hline 94377 & $945^{\cdot 6}$ & $946 \cdot 2$ & $947 \cdot 7$ \\
\hline 100.9 & $99 \cdot 7$ & $99 \cdot 8$ & $99^{\circ} 4$ \\
\hline $\begin{array}{c}\text { I92. } 8 \\
\text { I } 8.94\end{array}$ & $\begin{array}{c}100 \cdot 2 \\
18.39\end{array}$ & $\begin{array}{l}75.7 \\
18.06\end{array}$ & $\begin{array}{l}5 \mathrm{I} \cdot 7 \\
18 \cdot 19\end{array}$ \\
\hline $4 \cdot 53$ & $4 \div 39$ & $4 \cdot 32$ & $4 \cdot 35$ \\
\hline
\end{tabular}

- Prepared by V. W. Eves \& Co. Ltd, Beta Works, Fowler Road, Hainault, Essex; containing (g/kg): retinol 0.40 , cholecalciferol $0.0025, \alpha$-tocopheryl acetate 10.00 , ascorbic acid 40.00 , choline chloride I50.00, myo-inositol 10.00, nicotinic acid 4.00, riboflavin $x \cdot 00$, pyridoxine hydrochloride $1 \cdot 00$, thiamin hydrochloride $\mathrm{x} \cdot 00$, calcium pantothenate $3 \cdot 00$, biotin 0.02 , folic acid 0.10 , cyanocobalamin 0.002 , stabilized by dispersion on a glucose base.

+ Dunn salt mixture containing $(\mathrm{g} / \mathrm{kg})$ : calcium orthophosphate $434^{\circ} \circ$, potassium chloride $271 \cdot 0$, disodium hydrogen phosphate I I4.2, magnesium sulphate $0 \cdot 20$, sodium fluoride $0 \cdot 0 \mathrm{I}$.

\section{Determination of intake of digestible and metabolizable energy $(\mathrm{ME})$}

In Expt I the rats were housed in cages with wire-mesh floors. Each cage was suspended over a large evaporating-dish covered with fine nylon gauze. Faeces were held on the gauze and the urine was collected in the dish, which contained dilute sulphuric acid. Collections were made over $5 \mathrm{~d}$ periods. Samples of diet and of dried faeces and urine were ignited in an adiabatic bomb calorimeter.

In Expt 2 the rats were housed in cages with wire mesh floors and faeces and urine were collected on blotting-paper. Faeces only were collected for energy determinations and the amount of ME was calculated using factors for urine energy derived from the results of Expt $\mathrm{I}$. In the instance of the ad lib.-fed animals, spilt food was separated from the faeces each day using a domestic sieve. At the end of the experiment the paper was impregnated with dried urine and food which had dissolved in the urine (McCracken, I968a). The weight of dissolved food was estimated from the initial and final weight of the paper by making a correction for the weight of dried urine. The intake of ME was again calculated by subtracting a value for urine energy (McCracken, 1968 a) from the digested energy intake.

\section{Analysis of the carcasses}

Because studies of liver enzyme levels were done using some of the animals, all tube-fed rats were fed for the last time on the morning of the 8 th or $I_{5}$ th day, $I h$ before they were due to be killed. They were weighed before and after they were killed. The liver and intestinal tract were removed immediately and gut contents were 
Table 2. Expt r. Details of experimental groups of rats tube-fed diets providing high $(6 \mathrm{~g}$ dry matter (DM)/d) or low $(4 \mathrm{~g} \mathrm{DM} / \mathrm{d})$ energy intakes and high $(200 \mathrm{~g} / \mathrm{kg})$ or low (75 or $5 \circ \mathrm{g} / \mathrm{kg}$ ) protein contents from $3 \mathrm{I}$ d of age

\begin{tabular}{|c|c|c|c|c|c|c|}
\hline $\begin{array}{l}\text { Group } \\
\text { no. }\end{array}$ & $\begin{array}{l}\text { Energy } \\
\text { intake }\end{array}$ & $\begin{array}{l}\text { Solid food } \\
\text { intake }(g / d)\end{array}$ & $\begin{array}{l}\text { Length of } \\
\text { expt (d) }\end{array}$ & $\begin{array}{c}\text { Protein } \\
\text { level }\end{array}$ & Diet* & Comparison \\
\hline I & High & 6 & 7 & High & & Same energy, \\
\hline 2 & High & 6 & 7 & Low & 45 & $\begin{array}{l}\text { different protein } \\
\text { Same protein, }\end{array}$ \\
\hline 3 & Low & 4 & 7 & Low & 3 & different energy \\
\hline $\begin{array}{l}4 \\
5 \\
6\end{array}$ & $\begin{array}{c}\text { Low } \\
\text { Low } \\
\text { Starting controls }\end{array}$ & $\begin{array}{l}4 \\
4\end{array}$ & $\begin{array}{l}14 \\
14\end{array}$ & $\begin{array}{l}\text { High } \\
\text { Low }\end{array}$ & $\left.\begin{array}{l}I \\
3\end{array}\right\}$ & $\begin{array}{l}\text { Same energy, } \\
\text { different protein }\end{array}$ \\
\hline
\end{tabular}

discarded. The stomach and intestines were returned to the carcass, which was again weighed. Carcasses were individually analysed. They were homogenized using the method of Hartsook \& Hershberger (I963) and samples were taken for determination of DM and protein contents. Fat content and gross energy were determined on the dry material. Protein content was determined by the Kjeldahl method using mercury as the catalyst, fat content was determined by extraction with light petroleum (b.p. $\left.40-60^{\circ}\right)$ in a Soxhlet apparatus and gross energy was determined using an adiabatic bomb calorimeter. Liver protein content was determined using a micro-Kjeldahl procedure and liver lipid content by the method of the British Standards Institution (I95I).

\section{Experimental design}

Expt I. Thirty rats, aged $28 \mathrm{~d}$ and weighing approximately $45 \mathrm{~g}$, were separated into six groups (Table 2). They were all tube-fed with diet I in increasing amounts over a $3 \mathrm{~d}$ acclimatization period, and then placed on the experimental treatments at $3 \mathrm{I} \mathrm{d}$ of age. They were fed three times daily, at $01.00,09.00$ and 17.00 hours. The treatments imposed were high energy intake $(6 \mathrm{~g} \mathrm{DM} / \mathrm{d})$ or low energy intake $(4 \mathrm{~g}$ $\mathrm{DM} / \mathrm{d})$ and high-protein $(200 \mathrm{~g} / \mathrm{kg})$ or low-protein $(75$ or $50 \mathrm{~g} / \mathrm{kg})$ diets. The rats in groups $I$ and 2 provided a comparison of the effect of protein on energy utilization at an energy level close to the ad lib. intake of normal rats weighing $5 \circ \mathrm{g}$. Those in groups 2 and 3 provided a measure of the effect of energy intake at a constant low level of protein intake. Those in groups 4 and 5 were intended to provide a comparison of the effect of protein level on energy utilization when energy intake was just above that required to maintain body-weight.

Expt 2. Seventy-eight rats, aged $28 \mathrm{~d}$ and weighing approximately $45 \mathrm{~g}$, were separated into thirteen groups (Table 3 ). Ten groups were tube-fed with diet I for a $3 \mathrm{~d}$ period while the others were allowed continuous access to diet $\mathrm{I}$ in powder form. After the pre-experimental period, one group of tube-fed animals and one group of ad lib.-fed animals were killed as controls. The other nine groups of tube-fed animals were randomly allocated to a $3 \times 3$ factorial experimental design, the variables being dietary protein level $(50,100$ and $200 \mathrm{~g} / \mathrm{kg}$ ) and energy intake $3.5,6.0$ and $7.25 \mathrm{~g}$ 
Table 3. Expt 2. Details of experimental groups of rats tube-fed or fed ad lib. on diets providing high ( $7 \cdot 25 \mathrm{~g}$ dry matter (DM)/d), medium $(6 \cdot 0 \mathrm{~g} \mathrm{DM} / d)$ or low $(3.5 \mathrm{gM} / d)$ energy intakes and high $(200 \mathrm{~g} / \mathrm{kg})$, medium $(100 \mathrm{~g} / \mathrm{kg})$ or low $(5 \circ \mathrm{g} / \mathrm{kg})$ protein contents from $3 \mathrm{I} d$ of age

\begin{tabular}{|c|c|c|c|c|c|}
\hline $\begin{array}{c}\text { Group } \\
\text { no. }\end{array}$ & Energy intake & $\begin{array}{l}\text { Solid food intake } \\
(\mathrm{g} / \mathrm{d})\end{array}$ & Protein level & Diet* & $\begin{array}{l}\text { Method of } \\
\text { feeding }\end{array}$ \\
\hline $\begin{array}{l}\text { I } \\
2 \\
3\end{array}$ & Low & 3.5 & $\begin{array}{l}\text { Low } \\
\text { Medium } \\
\text { High }\end{array}$ & $\begin{array}{l}4 \\
2 \\
I\end{array}$ & $\begin{array}{l}\text { Tube } \\
\text { Tube } \\
\text { Tube }\end{array}$ \\
\hline $\begin{array}{l}4 \\
5 \\
6\end{array}$ & Medium & $6 \cdot 0$ & $\begin{array}{l}\text { Low } \\
\text { Medium } \\
\text { High }\end{array}$ & $\begin{array}{l}4 \\
2 \\
1\end{array}$ & $\begin{array}{l}\text { Tube } \\
\text { Tube } \\
\text { Tube }\end{array}$ \\
\hline $\begin{array}{l}7 \\
8 \\
9\end{array}$ & High & $7 \cdot 25$ & $\begin{array}{l}\text { Low } \\
\text { Medium } \\
\text { High }\end{array}$ & $\begin{array}{l}4 \\
2 \\
\text { I }\end{array}$ & $\begin{array}{l}\text { Tube } \\
\text { Tube } \\
\text { Tube }\end{array}$ \\
\hline $\begin{array}{l}10 \\
11 \\
12 \\
13\end{array}$ & $\begin{array}{l}\text { Ad lib. } \\
\text { Ad lib. } \\
\text { Starting controls } \\
\text { Starting controls }\end{array}$ & & $\begin{array}{l}\text { Low } \\
\text { Medium } \\
-\end{array}$ & $\begin{array}{l}4 \\
2 \\
- \\
-\end{array}$ & $\begin{array}{l}\text { Ad lib. } \\
\text { Ad lib. } \\
\text { Tube } \\
\text { Ad lib. }\end{array}$ \\
\hline
\end{tabular}

Table 4. Expt I. Digestible energy (DE) and metabolizable energy (ME) contents (as proportions of gross energy) of diets r (high-protein, $200 \mathrm{~g} / \mathrm{kg}$ ), 3 (low-protein, $75 \mathrm{~g} / \mathrm{kg}$ ) and 4 (low-protein, $50 \mathrm{~g} / \mathrm{kg}$ ), determined using pairs or triplets of rats

(Mean values for four determinations)

\begin{tabular}{|c|c|c|c|c|}
\hline & & Diet* & & \\
\hline & I & 3 & 4 & $\mathrm{SE}$ of mean \\
\hline $\mathrm{DE}$ & 0.9628 & 0.9492 & 0.9529 & 0.0034 \\
\hline ME & 0.9397 & 0.9404 & 0.9433 & 0.0034 \\
\hline $\mathrm{ME}(\mathrm{kJ} / \mathrm{g} \mathrm{DM})$ & $18 \cdot 36$ & $17 \cdot 96$ & 17.92 & - \\
\hline ( $\mathrm{kcal} / \mathrm{g} \mathrm{DM})$ & $4 \cdot 39$ & $4 \cdot 29$ & 4.28 & - \\
\hline
\end{tabular}

$\mathrm{DM} / \mathrm{d})$. Of the two remaining groups, one was offered diet $2 a d l i b$. and the other diet 4 ad lib. Because of the time involved in tube-feeding, the experiment was conducted in two parts, three animals per group being used in each block.

\section{RESULTS}

\section{Expt I}

The digestibility of dietary energy was higher for diet I than for the two lowprotein diets (diets 3 and 4 ) (Table 4). However, this difference was offset by the higher excretion of energy in the urine of rats given the high-protein diet. The ME contents of the three diets, expressed as a proportion of gross energy, were not significantly different and averaged 0.94I. The ME content, on a DM basis, ranged from 


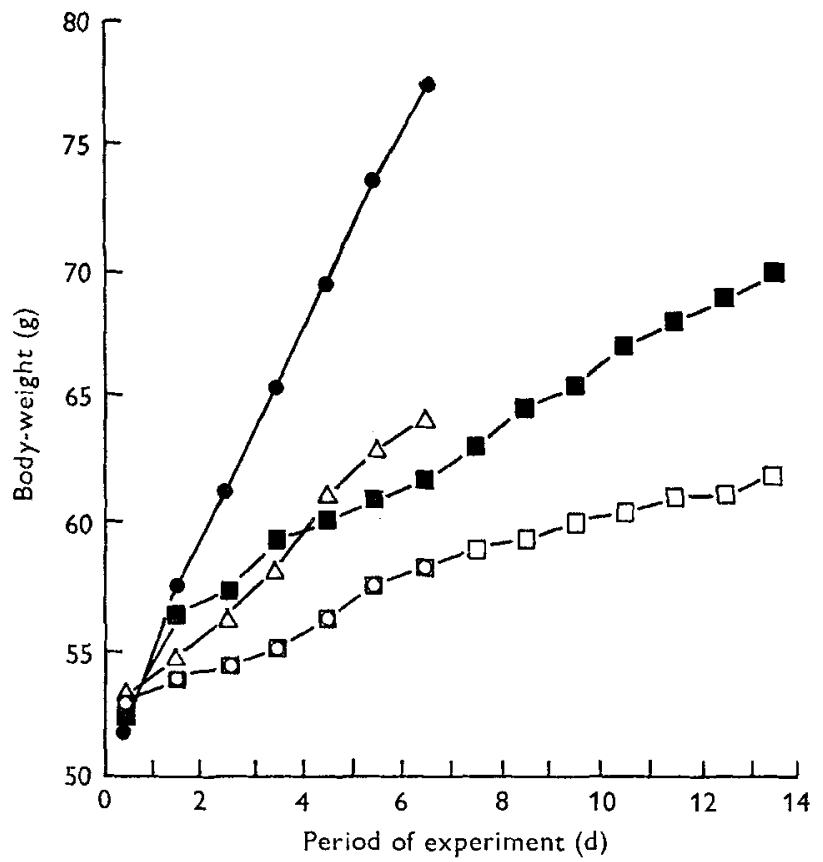

Fig. I. Expt I. Growth rates of rats tube-fed high- or low-protein diets for 7 or $14 \mathrm{~d}$. , High-protein $(200 \mathrm{~g} / \mathrm{kg})$, high energy intake $(6 \mathrm{~g}$ dry matter (DM)/d) (group I); $\triangle$, lowprotein $(5 \circ \mathrm{g} / \mathrm{kg})$, high energy intake (group 2$) ; 0$, low-protein $(75 \mathrm{~g} / \mathrm{kg}$ ), low energy intake (4 g DM/d) (group 3); $\mathbf{a}$, high-protein, low energy intake (group 4); $\square$, low-protein (75 g/ $/ \mathrm{kg}$ ), low energy intake (group 5).

$18.36 \mathrm{~kJ} / \mathrm{g}$ for diet $\mathrm{I}$ to $17.92 \mathrm{~kJ} / \mathrm{g}$ for diet 4 . Thus for all practical purposes the diets used were isoenergetic.

The growth rates of the different groups are shown in Fig. I. At the same energy intake rats given the higher level of protein grew more quickly. During the $7 \mathrm{~d}$ experimental period the rats in group $\mathrm{I}$ gained weight steadily at a rate similar to that reached by rats in the colony given stock diet $a d l i b$., and reached a final body-weight of $77 \mathrm{~g}$ compared to $64 \mathrm{~g}$ for the rats in group 2 . In the instance of the rats on the low-energy treatments those in group 4 reached a final average weight of $7 \circ \mathrm{g}$ at the end of the $\mathrm{I}_{4} \mathrm{~d}$ experimental period compared to only $62 \mathrm{~g}$ for the rats in group 5 .

Table 5 shows that the large differences in live-weight gain $(26.7$ or $9.4 \mathrm{~g}$ in rats with the high energy intake (groups $\mathrm{I}$ and 2 ) and $\mathrm{I} 7.8$ or $9.0 \mathrm{~g}$ with the low energy intake (groups 4 and 5)) were largely the result of changes in body water. For the animals fed on the low-protein diets at the high (group 2) and low (groups 3 and 5 ) levels of energy intake, $77^{.2}$ and $50.0 \%$ respectively of the live-weight gain was as DM compared to $35^{\circ} 6$ and $27.1 \%$ for the animals on the high-protein diet (groups I and 4 ). These differences were correlated with changes in the proportion of fat and protein in the gain. The rats in group I gained significantly more protein $(P<0.001)$ and significantly less fat $(P<0.01)$ than those in group 2 . Rats in group 4 deposited significantly more protein $(P<0.001)$ than those in group 5 . However, they were in negative fat balance whereas those in group 5 gained fat and the difference was sig- 
Table 5. Expt $\mathrm{x}$. Changes in body composition $(\mathrm{g})$ of rats tube-fed diets providing high (6 $\mathrm{g}$ dry matter (DM)/d) or low (4 $\mathrm{g} \mathrm{DM} / \mathrm{d})$ energy intakes and high $(200 \mathrm{~g} / \mathrm{kg})$ or low ( 75 or $5 \circ \mathrm{g} / \mathrm{kg}$ ) protein contents for 7 or $\mathrm{I}_{4} \mathrm{~d}$

(Mean values for five rats/group)

\begin{tabular}{|c|c|c|c|c|c|c|c|}
\hline $\begin{array}{c}\text { Group } \\
\text { no. }\end{array}$ & $\begin{array}{c}\text { Energy } \\
\text { intake }\end{array}$ & $\begin{array}{c}\text { Protein } \\
\text { level }\end{array}$ & Diet* & $\begin{array}{l}\text { Weight } \\
\text { gain }\end{array}$ & $\begin{array}{c}\text { DM } \\
\text { gain }\end{array}$ & $\begin{array}{c}\text { Protein } \\
\text { gain }\end{array}$ & $\begin{array}{l}\text { Fat } \\
\text { gain }\end{array}$ \\
\hline I & High & High & I & $26 \cdot 7$ & $9 \cdot 51$ & 5.08 & $3 \cdot 52$ \\
\hline 2 & High & Low & 4 & $9 \cdot 4$ & $7 \cdot 26$ & $1 \cdot 62$ & $5 \cdot 43$ \\
\hline 3 & Low & Low & 3 & $5 \cdot 5$ & $2 \cdot 80$ & $\mathrm{I} \cdot 5 \mathrm{I}$ & $0 \cdot 86$ \\
\hline 4 & Low & High & I & 17.8 & $4 \cdot 82$ & $5 \cdot 57$ & $I \cdot 74$ \\
\hline 5 & Low & Low & 3 & $9 \cdot 0$ & $4 \cdot 50$ & $2 \cdot 64$ & $I \cdot I 9$ \\
\hline \multicolumn{4}{|c|}{$\mathrm{SE}$ of mean $(23 \mathrm{df})$} & I.O & 0.53 & 0.20 & 0.49 \\
\hline
\end{tabular}

* For details, see Table I.

'Table 6. Expt x. Values for energy intake, retention and expenditure of rats tube-fed diets providing high (6 $g$ dry matter (DM)/d) or low ( $4 g \mathrm{DM} / d)$ energy intakes and high $(200 \mathrm{~g} / \mathrm{kg})$ or low $\left(75\right.$ or $50 \mathrm{~g} / \mathrm{kg}$ ) protein contents for 7 or $\mathrm{I}_{4} \mathrm{~d}$

(Mean values for five rats/group)

\begin{tabular}{|c|c|c|c|c|c|c|c|}
\hline \multirow[b]{2}{*}{$\begin{array}{c}\text { Group } \\
\text { no. }\end{array}$} & \multirow[b]{2}{*}{$\begin{array}{l}\text { Energy } \\
\text { intake }\end{array}$} & \multirow[b]{2}{*}{$\begin{array}{c}\text { Protein } \\
\text { level }\end{array}$} & \multirow[b]{2}{*}{ Diet* } & \multirow[b]{2}{*}{$\begin{array}{c}\text { ME } \\
\text { intake } \\
(\mathrm{kJ} / \mathrm{d})\end{array}$} & \multirow[b]{2}{*}{$\begin{array}{c}\text { Carcass } \\
\text { energy } \\
\text { gain } \\
(\mathrm{kJ} / \mathrm{d})\end{array}$} & \multicolumn{2}{|c|}{ Heat production } \\
\hline & & & & & & $(\mathrm{kJ} / \mathrm{d})$ & $\begin{array}{c}(\mathrm{kJ} / \mathrm{d} \\
\operatorname{per} \mathrm{kg} \\
\text { body-wt) }\end{array}$ \\
\hline I & High & High & $\mathbf{I}$ & $\mathrm{I} I 2 \cdot 5$ & $36 \cdot 8$ & $75 \cdot 7$ & II 63 \\
\hline 2 & High & Low & 4 & $x 04 \cdot 6$ & $35 \cdot 6$ & $69 \cdot 0$ & II 85 \\
\hline 3 & Low & Low & 3 & $65 \cdot 3$ & 10.0 & $55 \cdot 3$ & 993 \\
\hline 4 & Low & High & 1 & $66 \cdot 5$ & $4 \cdot 6$ & $6 x \cdot 9$ & 971 \\
\hline 5 & Low & Low & 3 & $64 \cdot 0$ & $7 \cdot 9$ & $5^{6 \cdot 1}$ & 959 \\
\hline \multicolumn{2}{|c|}{$\mathrm{SE}$ of mean ( $23 \mathrm{df})$} & & & & $2 \cdot 3$ & $2 \cdot 3$ & 35 \\
\hline
\end{tabular}

nificant $(P<0.00 \mathrm{I})$. As a result there was no significant difference in DM gain between groups 4 and 5, although group $\mathrm{I}$ showed a significant increase in DM $(P<0.01)$ compared to group 2. The third comparison which can be made is between groups 2 and 3 , where intakes of protein were similar but group 2 had a higher energy intake. There was no significant difference in gain of protein but highly significant differences $(P<0.00 \mathrm{I})$ in gain of body fat, DM and body-weight.

The results for energy retention and calculated daily heat production are summarized in Table 6. Although intakes of ME in groups $\mathrm{I}$ and 4 were slightly higher than those of groups 2 and 5 there were no significant differences in energy gain. However, daily heat production was significantly higher $(P<0.05)$ on the two highprotein treatments in comparison with the pair-fed, low-protein treatments, the differences being approximately 10\%. The effect of energy intake on heat production was clearly demonstrated by groups 2 and 3 . In order to eliminate the effect of bodyweight on the comparison of heat production between groups the results were also 
Table 7. Expt 2. Changes in body composition ( $g$ ) of rats tube-fed or fed ad lib. on diets providing high $(7.25 g$ dry matter (DM)/d), medium $(6 \cdot 0 \mathrm{~g} \mathrm{DM} / d)$ or low $(3.5 \mathrm{~g} \mathrm{DM} / d)$ energy intakes and high $(200 \mathrm{~g} / \mathrm{kg}$ ), medium (100 $\mathrm{g} / \mathrm{kg}$ ) or low (5० $\mathrm{g} / \mathrm{kg})$ protein contents

(Mean values for six rats/group)

\begin{tabular}{|c|c|c|c|c|c|c|}
\hline \multirow[b]{2}{*}{$\begin{array}{c}\text { Group } \\
\text { no. }\end{array}$} & \multicolumn{2}{|c|}{ Treatment } & \multirow[b]{2}{*}{$\begin{array}{c}\text { Carcass } \\
\text { weight gain }\end{array}$} & \multirow[b]{2}{*}{$\begin{array}{l}\text { DM } \\
\text { gain }\end{array}$} & \multirow[b]{2}{*}{$\begin{array}{l}\text { Fat } \\
\text { gain }\end{array}$} & \multirow[b]{2}{*}{$\begin{array}{c}\text { Protein } \\
\text { gain }\end{array}$} \\
\hline & $\begin{array}{l}\text { Energy } \\
\text { intake }\end{array}$ & $\begin{array}{c}\text { Protein } \\
\text { level }\end{array}$ & & & & \\
\hline $\begin{array}{l}\text { I } \\
2 \\
3\end{array}$ & Low, tube-fed & $\begin{array}{l}\text { Low } \\
\text { Medium } \\
\text { High }\end{array}$ & $\begin{array}{r}2.48 \\
6.52 \\
10.54\end{array}$ & $\begin{array}{l}2 \cdot 26 \\
I \cdot 96 \\
2 \cdot 29\end{array}$ & $\begin{array}{r}1.24 \\
0.37 \\
-0.91\end{array}$ & $\begin{array}{l}0.51 \\
1 \cdot 27 \\
2 \cdot 84\end{array}$ \\
\hline $\begin{array}{l}4 \\
5 \\
6\end{array}$ & $\begin{array}{l}\text { Medium, } \\
\text { tube-fed }\end{array}$ & $\begin{array}{l}\text { Low } \\
\text { Medium } \\
\text { High }\end{array}$ & $\begin{array}{l}10.77 \\
16.95 \\
2.5 .97\end{array}$ & $\begin{array}{l}7 \cdot 12 \\
7 \cdot 80 \\
9 \cdot 38\end{array}$ & $\begin{array}{l}5 \cdot 57 \\
4 \cdot 78 \\
3 \cdot 94\end{array}$ & $\begin{array}{l}1 \cdot 31 \\
2 \cdot 37 \\
4 \cdot 34\end{array}$ \\
\hline $\begin{array}{l}7 \\
8 \\
9\end{array}$ & High, tube-fed & $\begin{array}{l}\text { Low } \\
\text { Medium } \\
\text { High }\end{array}$ & $\begin{array}{l}15 \cdot 62 \\
24.87 \\
30 \cdot 67\end{array}$ & $\begin{array}{l}10 \cdot 63 \\
12 \cdot 19 \\
12.87\end{array}$ & $\begin{array}{l}8 \cdot 37 \\
8 \cdot 34 \\
6 \cdot 96\end{array}$ & $\begin{array}{l}I \cdot 43 \\
3 \cdot 06 \\
4 \cdot 86\end{array}$ \\
\hline $\begin{array}{l}\text { Io } \\
\text { II }\end{array}$ & $A d l i b$ & $\begin{array}{l}\text { Low } \\
\text { Medium }\end{array}$ & $\begin{array}{r}6 \cdot 93 \\
25 \cdot 28\end{array}$ & $\begin{array}{r}5: 29 \\
\text { II } 94\end{array}$ & $\begin{array}{l}3 \cdot 43 \\
6 \cdot 49\end{array}$ & $\begin{array}{l}I: 43 \\
4 \cdot 25\end{array}$ \\
\hline & $2 \mathrm{df})$ & & 0.94 & 0.40 & 0.40 & 0.17 \\
\hline $\begin{array}{r}\text { Analysi } \\
\text { Effec } \\
\text { Effec } \\
\text { Effec }\end{array}$ & $\begin{array}{l}\text { riance of } 3 \times 3 \text { fa } \\
\text { otein } \\
\text { ergy } \\
\text { teraction }\end{array}$ & ial experim & $\begin{array}{c}\text { nt on tube-fec } \\
* * * \\
* * * \\
* * *\end{array}$ & $\begin{array}{l}\text { s*** } \\
* * * \\
* * *\end{array}$ & $\begin{array}{l}* * * \\
* * * \\
* * *\end{array}$ & $\begin{array}{l}* * * * \\
* * * \\
* * * *\end{array}$ \\
\hline
\end{tabular}

calculated on a body-weight basis. When expressed on this basis there was no significant difference in the heat production of groups given the same energy intake.

\section{Expt 2}

The results are summarized in Tables 7 and 8 . The values for the nine groups of tube-fed rats were analysed as a $3 \times 3$ factorial design using the analysis of variance technique. Protein level and energy intake exerted highly significant effects $(P<$ 0.001 ) on gain of carcass weight, DM, fat and protein (Table 7 ). There was a significant interaction $(P<0.00 \mathrm{I})$ of protein and energy on carcass gain, the effect of protein level being greater at the higher levels of energy intake. Gain of body protein and DM were also significantly affected $(P<0.0 \mathrm{I})$ by a similar protein-energy interaction. As in Expt $\mathrm{I}$ there was no effect of protein on DM gain at the low level of energy intake but a significant increase in DM gain with increased protein level at the higher levels of energy intake. Fat deposition was negatively correlated with increasing dietary protein level and, in agreement with the results of Expt I, a negative fat balance occurred with the low-energy, high-protein treatment (group 3).

Striking differences were observed in the body composition of the two pairs of groups used for comparison of tube-feeding and ad lib. feeding. With the low-protein diet the tube-fed rats gained significantly more weight $\left(P<0^{\circ} 0 \mathrm{I}\right)$ and more fat and DM $(P<0.00 \mathrm{I})$ than their ad lib.-fed counterparts on an isoenergetic intake. There 
Table 8. Expt 2. Values for energy intake, retention and expenditure of rats tube-fed or fed ad lib. on diets providing high ( $7.25 \mathrm{~g}$ dry matter (DM)/d), medium (6.0 $\mathrm{g} \mathrm{DM} / d)$ or low $(3.5 \mathrm{~g} \mathrm{DM} / d)$ energy intakes and high $(200 \mathrm{~g} / \mathrm{kg})$, medium (100 $\mathrm{g} / \mathrm{kg})$ or low $(5 \circ \mathrm{g} / \mathrm{kg})$ protein contents for ro $d$

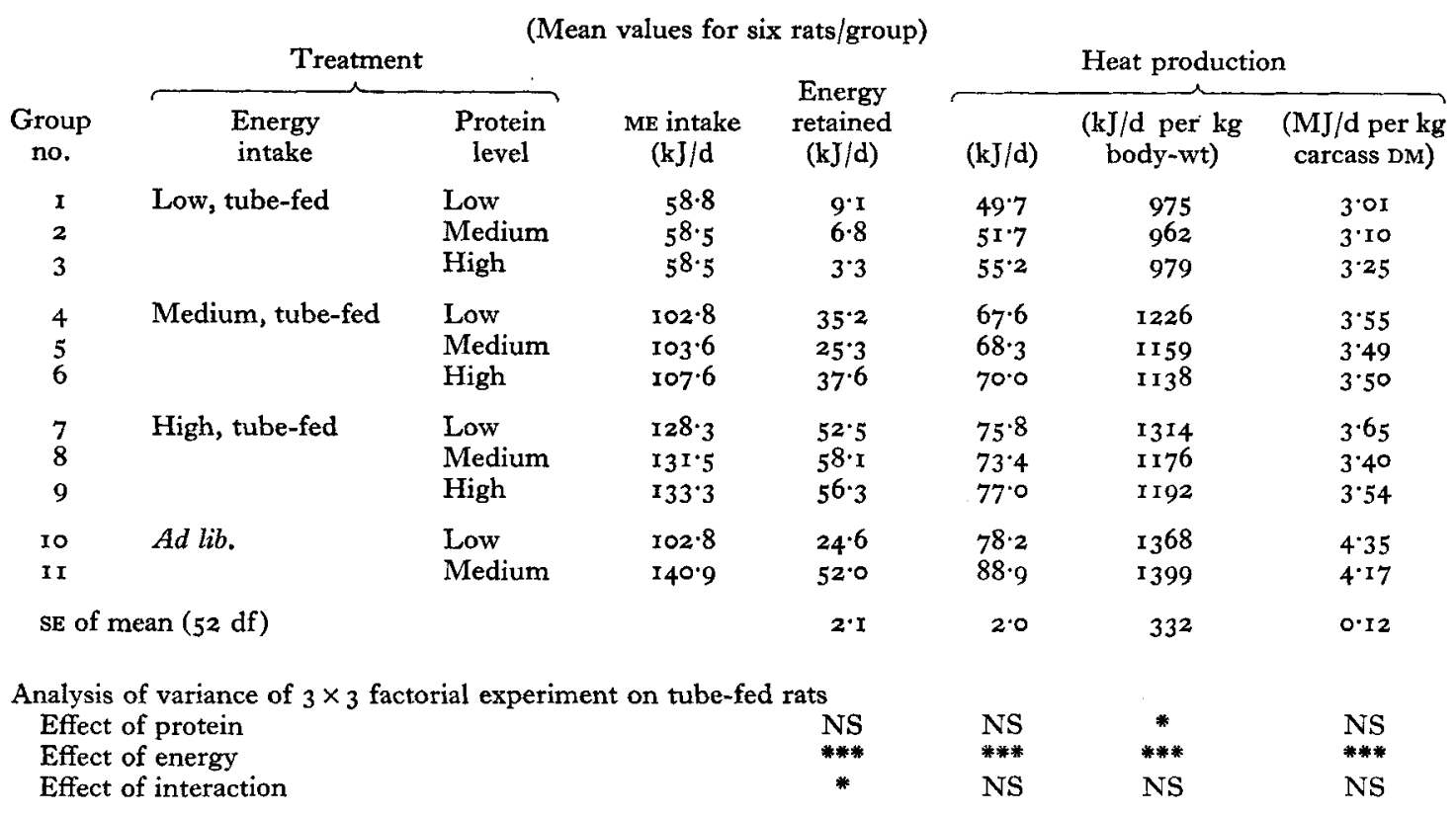

ME, metabolizable energy; NS, not significant.

$* P<0.05, * * * P<0.001$.

was no significant difference in gain of protein. On the medium-protein diet, the ad lib. group had a higher energy intake than the tube-fed group on the high energy intake (Table 8) and this complicated the comparison. There was no significant difference in gain of carcass weight or DM. However, gain of body fat was significantly higher $(P<0.01)$ and gain of protein significantly lower $(P<0.001)$ for the tube-fed group.

Table 8 summarizes the intake, retention and expenditure of energy of the eleven groups. The daily intake of energy on the low-intake treatments (groups I-3) was lower than in Expt I. The medium-intake treatments (groups 4-6) correspond to the high-intake treatments in Expt $I$ and the high-intake treatments (groups 7-9) had $25-30 \%$ higher intakes. Analysis of variance of the results for the nine tube-fed groups using a $3 \times 3$ factorial design indicated that dietary protein level had no significant effect on energy retention though, predictably, the latter was significantly affected by energy intake. A significant $(P<0.05)$ protein-energy interaction existed for energy retention, which was lowest with the high-protein diet at the low level of intake and with the low-protein diet at the high level of intake. The values agreed closely with the results of Expt I. The lack of a significant effect of protein on daily 
heat production was not entirely in agreement with the results of Expt $\mathrm{I}$, but once again there was a trend of increasing heat production with increased protein level which exceeded $10 \%$ on the low-energy-intake treatments.

When heat production was expressed per unit body-weight, there was a significant $(P<0.05)$ increase with the low level of dietary protein. Although the protein-energy interaction failed to reach statistical significance, there were no differences between the values obtained at the low level of energy intake and these were in close agreement with the results of Expt $\mathrm{r}$. There was an apparent trend for the differences to increase as the level of energy intake increased. However, when heat production was expressed on a basis of dry weight to take account of the large differences in body water, protein had no significant effect and there was no protein-energy interaction on heat production.

The differences in energy retention and expenditure between tube-fed rats and their ad lib.-fed counterparts are of major importance. With the low-protein diet, where average intakes of $\mathrm{ME}$ were identical, the energy retention of the ad lib.-fed group was $30 \%$ lower, the difference being highly significant $(P<0.001)$. With the mediumprotein diet the energy retention of the ad lib.-fed group was significantly $(P<0.05)$ lower than that of their tube-fed counterparts, although energy intake was higher. Daily heat production of both ad lib.-fed groups was significantly $(P<0.00 \mathrm{I})$ higher than that of the tube-fed groups irrespective of the basis of comparison used.

\section{DISCUSSION}

The results for the 'meal-fed' and ad lib. groups in Expt 2 agree entirely with previous observations using normal diets (Cohn et al. 1957; Fabry \& Braun, 1967), and support the hypothesis on which the experiments were based. The large increases in body fat with the 'meal-fed' regimens also provide support in vivo for the results of Beaton, Feleki, Szlavko \& Stevenson (1964) who found that the ability of isolated adipose tissue slices to incorporate $\left[{ }^{4} \mathrm{C}\right]$ acetate into fatty acids was increased to a similar degree by meal-feeding diets containing casein at levels of $50 \mathrm{or} 200 \mathrm{~g} / \mathrm{kg}$. The results for 'meal-fed' animals at each level of feeding indicate an absolute increase in fat deposition with decreasing protein level. This agrees with the observation of Leveille ( 1967$)$, that incorporation of $\left[\mathrm{U}-{ }^{14} \mathrm{C}\right]$ glucose and $\left[{ }^{14} \mathrm{C}\right]$ leucine into fatty acid and triglyceride was enhanced with low-protein diets.

The results for energy retention and heat production in both experiments are clearly contrary to those of all previous 'pair-feeding' experiments where intake was not controlled, including those of the author (McCracken, I $968 a$ ). It would therefore appear that the factor mainly responsible for the previously reported differences is the pattern of intake. Indeed the results of Expt $\mathrm{I}$ would suggest that this was the sole factor. However the results of Expt 2 are not as clear, depending on the basis of comparison used. Although the same conclusion may be drawn as in Expt I when total heat production is considered, it could be argued that a comparison on the basis of 'equalized' body-weight would be more valid, since the maintenance component is generally regarded as being related to some function of live weight. Using this 
Table 9. Comparison of energy utilization of 'paired-gain' rats tube-fed high-and lowprotein diets

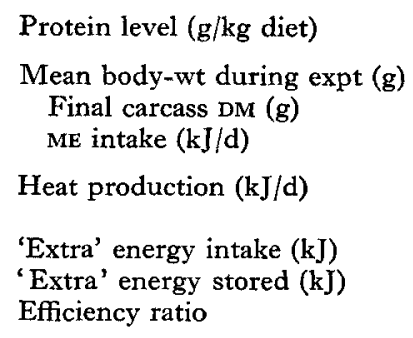

\begin{tabular}{|c|c|c|c|}
\hline 200 & $5^{\circ}$ & 100 & $5^{\circ}$ \\
\hline $\begin{array}{l}56 \cdot 3 \\
18 \cdot 13 \\
58 \cdot 5\end{array}$ & $\begin{array}{c}55.3 \\
22 \cdot 59 \\
102 \cdot 8\end{array}$ & $\begin{array}{c}58 \cdot 8 \\
23.76 \\
103.4\end{array}$ & $\begin{array}{c}57 \cdot 7 \\
26 \cdot 10 \\
128 \cdot 3\end{array}$ \\
\hline $55^{\prime 2}$ & $67 \cdot 6$ & $68 \cdot 2$ & $75 \cdot 8$ \\
\hline \multicolumn{2}{|c|}{$44 \cdot 3$} & \multicolumn{2}{|c|}{24.9} \\
\hline \multicolumn{2}{|c|}{$31^{\circ} 9$} & \multicolumn{2}{|c|}{$17 \cdot 3$} \\
\hline \multicolumn{2}{|c|}{0.72} & \multicolumn{2}{|c|}{0.70} \\
\hline
\end{tabular}

DM, dry matter; ME, metabolizable energy.

approach, a conflict arises between the results of the two experiments at higher levels of energy intake.

There is, however, a third possible basis for comparison. It is clear from the results presented that most of the difference in live weight between animals on the same level of energy intake was accounted for by changes in body water. Under these circumstances it is doubtful whether a single function of live weight would be applicable to all protein treatments and therefore the results were also compared on the basis of carcass DM. It is clearly impossible to say which method of comparison is the most valid. Nevertheless it should be noted that at the low level of energy intake, when differences in body-weight and carcass composition were less pronounced, the heat production of the rats on the low-protein treatment was at least as low as that of those on the normal diet.

The results at the higher levels of intake may either be interpreted as proof that protein level has no effect when pattern of intake is controlled by gastric intubation or, in Expt 2, as an indication that some difference remains to be accounted for. It is worth noting that in Expt 2, the intake of the rats in group 7 was $25 \%$ higher than that of the corresponding ad lib.-fed group.

It is also possible to make comparisons in the instance of two pairs of groups in Expt 2 which correspond to a 'paired-gain' situation. Table 9 shows that in both instances the animals on the low-protein diet required more energy to maintain the same rate of body-weight gain. However, this was due to large differences in the composition and energy value of the gain, as shown by the higher carcass DM, and not to any difference in utilization of energy. In both instances the extra energy ingested by the low-protein, 'paired-gain' group was converted to body gain with an efficiency of approximately 0.70. This contrasts with the results of Miller \& Payne (1962) and McCracken (I968a), who found that less than $40 \%$ of the extra energy ingested by the low-protein, 'paired-gain' group was converted to body tissue when the pattern of intake was not controlled.

In both the above-mentioned experiments the rats given restricted amounts of the normal diet were slightly in negative energy balance. It is possible therefore to compute the requirement for maintenance of energy equilibrium. Miller \& Payne (1963) 
published a value of $107 \mathrm{kcal} / \mathrm{kg}$ body-weight $(\mathrm{W})^{0.75}$ corresponding to $449 \mathrm{~kJ} / \mathrm{W}^{0.75}$. The results of McCracken ( $1968 a$ ) produced a value of 453 . In the present experiments the animals on the low-energy treatments were all in positive energy balance. Assuming an efficiency of 0.70 to correct for the small amounts of energy gained, the maintenance requirement for groups 3, 4 and 5 in Expt I was calculated as 449, 46r and $445 \mathrm{~kJ} / \mathrm{W}^{0 \cdot 75}$ respectively and for groups $\mathrm{I}, 2$ and 3 in Expt 2 the corresponding values were $433,44 \mathrm{I}$ and $433 \mathrm{~kJ} / \mathrm{W}^{0.75}$.

It would seem, therefore, that the requirement for maintenance of energy equilibrium in the young rat is unaffected by dietary protein level when the pattern of intake is controlled by gastric intubation and that the results obtained by this method are in close agreement with those obtained when rats consume their daily ration in a restricted time.

Only two reports are known to the author of experiments where the energy retention of rats given diets of different protein level was measured under conditions of controlled pattern of intake. The first (Stock, 1972) relates to a 'paired-gain' situation with either no feeding pattern imposed or one $2 \mathrm{~h}$ meal/d. The results obtained in the former instance agree with those of Miller \& Payne (1962) and McCracken (1968a). However, contrary to the results presented above, he found that when the feeding pattern was controlled, differences still existed between the low-protein and highprotein groups. This conflict cannot be clearly resolved. However, it is worth noting that the values obtained on the normal-protein diet with no feeding pattern imposed and on the low-protein diet with rats given one $2 \mathrm{~h}$ meal/d are similar to those of the author. Only the value for the rats given the normal diet in one $2 \mathrm{~h}$ meal/d appears anomalous in that the requirement for weight maintenance, corresponding to $336 \mathrm{~kJ} / \mathrm{W}^{0.75}$, is unusually low. Since the experiment was not replicated the validity of this single result is an open question. The other report relates to a 'pair-feeding' situation and is of particular interest because the control was accidental. Johnson, Hogan \& Ashworth (1936) did a very careful series of experiments using diets containing 80 and $250 \mathrm{~g}$ protein $/ \mathrm{kg}$. They found that more fat and less protein were deposited by the animals consuming the low-protein diet but that there was no difference in the energy retention or heat production of the groups compared. Although their results have been ignored and even misquoted by later workers they assume a new significance in the light of the present findings. Johnson et al. (1936) did not feed the protein-restricted animals ad lib. because they found that excessive spillage could be avoided by providing access to the food for only a few hours/d. Thus they unwittingly minimized differences in pattern of intake and obtained results which differed from those of Forbes et al. (1935) and later workers but which agree completely with those presented in this paper.

Most studies on the effect of dietary deficiencies on the energy metabolism of the rat have used the 'pair-feeding' technique (Kleiber, 1945). The present results are of fundamental importance to the interpretation of much of the published information since in general the pattern of intake was not controlled. There is clearly a need for a reappraisal of the effect of dietary deficiencies on energy metabolism under conditions of controlled intake. Gastric intubation appears to be a satisfactory means of 
achieving this end and has an advantage over other methods in that both the amount of food eaten and the pattern of intake can be controlled.

Part of the work reported was done under the supervision of Dr E. M. Widdowson at the Infant Nutrition Research Division, Cambridge, and was made possible by a Medical Research Council Scholarship for Training in Research Methods. Thanks are due to $\mathrm{Dr}$ Widdowson for her continuous interest and helpful advice and to S. T. C. Weatherup of the Agricultural Biometrics Division, Department of Agriculture, Northern Ireland, for help with statistical analysis.

\section{REFERENCES}

Beaton, J. R., Feleki, V., Szlavko, A. J. \& Stevenson, J. A. F. (1964). Can. F. Physiol. Pharmac. 42, 665.

British Standards Institution (195I). British Standard 1743: 1957. London: British Standards Institution.

Cohn, C., Joseph, D. \& Shrago, E. (1957). Metabolism 6, 381.

Fabry, P. \& Braun, T. (I967). Proc. Nutr. Soc. 26, I44.

Forbes, E. B., Swift, R. W., Black, A. \& Kahlenberg, O. J. (1935). F. Nutr. 10, 46r.

Fraps, G. S. (193I). Bull. Tex. agric. Exp. Stn no. 436.

Hamilton, T. S. (1939a). F. Nutr. 17, 565.

Hamilton, T. S. $(1939 b)$. F. Nutr. 17, 583 .

Hartsook, E. W. \& Hershberger, T. V. (1963). Proc. Soc. exp. Biol. Med. r13, 973.

Hogan, A. G. \& Pilcher, R. W. (I933). Res. Bull. Mo. agric. Exp. Stn no. I95.

Johnson, S. R., Hogan, A. G. \& Ashworth, U. S. (1936). Res. Bull. Mo. agric. Exp. Stn no. 246

Kleiber, M. (1945). Nutr. Abstr, Rev. 15, 207.

Leveille, G. A. (1967). F. Nutr. 91, 25.

Loveless, B. W., Williams, P. \& Heaton, F. W. (1972). Br. F. Nutr. 28, 261.

McCracken, K. J. (I $968 a$ ). Energy metabolism of young rats subjected to a deficiency of calories or of protein. PhD Thesis, University of Cambridge.

McCracken, K. J. (1968b). Proc. Nutr. Soc. 27, 41A.

Miller, D. S. \& Payne, P. R. (1962). F. Nutr. 78, 255.

Miller, D. S. \& Payne, P. R. (1963). F. theor. Biol. 5, 398.

Mitchell, H. H. (1964). Comparative Nutrition of Man and Domestic Animals Vol. 2. New York: Academic Press.

Mitchell, H. H. \& Carman, G. G. (1926). F. biol. Chem. 68, 165.

Möllgaard, H. (1923). C.r. Congr. int. l'Elevage de l'Espece Bovine, Hague I B, 7 I.

Pocknee, R. C. \& Heaton, F. W. (1974). Proc. Nutr. Soc. 33, 27A.

Stock, M. J. (1972). Proc. Nutr. Soc. 31, r 5 A.

Tepperman, H. M. \& Tepperman, J. (1964). Fedn Proc. Fedn Am. Socs exp. Biol. $23,73$.

Tepperman, J. \& Tepperman, H. M. (I958). Am. F. Physiol. 193, 55. 